\title{
New Evidence on Carbetocin: Another Arrow in Our Quiver
}

\author{
Steve Hodgins ${ }^{a}$
}

Carbetocin is more heat stable than oxytocin with at least equivalent efficacy for preventing postpartum hemorrhage. It will certainly be helpful if the supplier can make it available in low-income country settings at a price comparable to oxytocin. But even so, programs will still need oxytocin and other uterotonic medications.

O n August 23, 2018, the New England Journal of Medicine published the results of the large, multicountry, World Health Organization (WHO) CHAMPION trial, ${ }^{1}$ a non-inferiority study testing carbetocin against synthetic oxytocin for prevention of postpartum hemorrhage. Publication of this trial created some buzz in the international media, with reports in BBC and the New York Times, including quotes from WHO officials claiming that wider use of carbetocin could "revolutionize our ability to keep mothers ... alive." 2 That may be claiming too much.

Uterotonics have a critically important role in obstetrics, notably for labor induction and augmentation and for prevention and treatment of postpartum hemorrhage. Whatever the indication, in using these drugs clinicians seek to optimize for efficacy and safety, taking into accountamong other considerations-characteristics of the specific drugs, dosage, route of administration, clinical indications, and patient characteristics.

Synthetic oxytocin has been widely used in obstetrical practice since the 1960s. Carbetocin-more recently introduced-is an oxytocin analog, acting on oxytocin receptors in the myometrium, but in some important respects it differs from synthetic oxytocin: its half-life in circulation is considerably longer and it is more heat stable. $^{3}$

\section{CLINICAL EFFICACY}

Heat-related degradation of oxytocin is well-documented, ${ }^{4}$ and studies in both Africa ${ }^{5}$ and South Asia ${ }^{6}$ have found a significant proportion of oxytocin sold at retail level falling outside of manufacturer specifications. The greater heat stability of carbetocin means there is more certainty about the actual delivered dose than there is for oxytocin. But this doesn't necessarily translate into any significant difference in clinical efficacy. In the new

\footnotetext{
aEditor-in-Chief, Global Health: Science and Practice Journal, and Associate Professor, School of Public Health, University of Alberta, Edmonton, Alberta, Canada.

Correspondence to Steve Hodgins (shodgins@ghspjournal.org).
}

study, the authors claim oxytocin has "unsatisfactory real-world efficacy as a result of sensitivity to heat."1 However, the evidence they cite consists only of assays of the amount of active pharmaceutical ingredient in the vials sampled, ${ }^{7}$ not effects on patient outcomes.

A recently published trial ${ }^{8}$ provides good evidence that route of administration matters; in a doubleblinded, head-to-head comparison of oxytocin $10 \mathrm{IU}$ administered intravenously versus intramuscularly, the investigators found significant differences in clinically important endpoints, with better results for intravenous administration than for intramuscular for blood loss $\geq 1000$ cc (adjusted odds ratio [aOR], 0.54; 95\% confidence interval [CI], 0.32 to 0.91 ) and need for transfusion (aoR, $0.31 ; 95 \% \mathrm{CI}, 0.13$ to 0.70 ). So route of administration matters. But no similarly unequivocal evidence is available for a difference in clinical efficacy between 5 IU and 10 IU. A Cochrane review by Westhoff $^{9}$ found 5 trials comparing either 5 IU or 10 IU to placebo. In a pooled comparison, with blood loss $\geq 500$ cc as the endpoint (Analysis 2.4), pooled effect sizes were similar for 5 IU (relative risk [RR], 0.42; 95\% CI, 0.17 to 1.01 ) and $10 \mathrm{IU}$ (RR, $0.47 ; 95 \% \mathrm{CI}, 0.38$ to 0.59 ). The Table looks a little more closely at these trials.

From these trial results, it is certainly fair to say that evidence for clinical efficacy is better for 10 IU than for 5 IU (and that evidence for effectiveness of intramuscular administration of oxytocin 5 IU is particularly weak) ${ }^{*}$; it would not be fair to say the evidence is definitive.

\section{SAFETY}

In addition to efficacy, an important consideration for uterotonics is safety, particular when used for labor augmentation. In many parts of the world, oxytocin (and sometimes other uterotonics) is commonly used for

*The Abdel-Aleem trial, ${ }^{13}$ with a total sample of 1,950, provides robust evidence of clinical benefit of 10 IU administered intramuscularly. The only 2 studies using $5 \mathrm{IU}$ administered intramuscularly were De Groot ${ }^{10}$ and Poueschmann, ${ }^{11}$ both of which were very small and therefore lacking in adequate statistical power for our clinical endpoints of interest. As a result, they provide little evidence one way or the other about clinical efficacy of $5 \mathrm{IU}$ administered intramuscularly. 
TABLE. Summary of Current Evidence on 5 IU or 10 IU Oxytocin Compared With Placebo

\begin{tabular}{|c|c|c|c|c|c|c|}
\hline Study & $\mathbf{N}$ & $\begin{array}{l}\text { Route of } \\
\text { Administration }\end{array}$ & $\begin{array}{l}\text { Dose } \\
\text { (IU) }\end{array}$ & $\begin{array}{l}\text { RR for Blood } \\
\text { Loss } \geq 500 \mathrm{cc} \\
(95 \% \mathrm{Cl})\end{array}$ & $\begin{array}{l}\text { Other Clinically Important Endpoints: } \\
\text { RR ( } 95 \% \mathrm{CI})\end{array}$ & Methodologic Issues \\
\hline $\begin{array}{l}\text { Poeschmann } \\
(1991)^{11}\end{array}$ & 52 & IM & 5 & $0.60(0.27,1.33)$ & $\begin{array}{l}\text { Blood loss } \geq 1000 \text { cc: } 0.57(0.10,3.14) \\
\text { Therapeutic uterotonic needed: } \\
0.17(0.001,3.42)\end{array}$ & $\begin{array}{l}\text { Trial ended early due to "organizational } \\
\text { issues" }\end{array}$ \\
\hline $\begin{array}{l}\text { Pierre } \\
(1992)^{12}\end{array}$ & 970 & & 5 & $0.29(0.21,0.41)$ & Blood loss $\geq 1000$ cc: $0.33(0.14,0.77)$ & $\begin{array}{l}\text { Allocation to treatment vs. control done } \\
\text { even-odd, by order of registration } \\
\text { Those measuring blood loss were not } \\
\text { blinded to treatment status }\end{array}$ \\
\hline $\begin{array}{l}\text { Abdel-Aleem } \\
(2010)^{13}\end{array}$ & 1,950 & IM & 10 & $0.53(0.39,0.74)$ & $\begin{array}{l}\text { Blood loss } \geq 1000 \mathrm{cc:} 0.52(0.13,2.08) \\
\text { Therapeutic uterotonic needed: } \\
0.39(0.26,0.58)\end{array}$ & \\
\hline
\end{tabular}

augmentation under unsafe conditions (not reliably ruling out mechanical obstruction, administering the drug intramuscularly or by intravenous bolus, failing to closely monitor the laboring woman, and not having timely access to emergency cesarean delivery). Because of dangers associated with uterotonic use during labor, oxytocin is designated as a high-alert medication. ${ }^{15}$ Wide use under unsafe conditions makes an important contribution to poor birth outcomes in South Asia $^{16-20}$ and elsewhere. ${ }^{21}$

Carbetocin would certainly be no safer in this respect. Given its considerably longer half-life, arguably, deploying it widely in place of oxytocin could increase risk of adverse outcomes related to such inappropriate use-notably fetal asphyxia and uterine rupture.

\section{ACCESS}

Oxytocin is an inexpensive medication; the median bulk price documented in the International Medical Products Price Guide from Management Sciences for Health is US\$0.17 for a $10 \mathrm{IU} \mathrm{amp}^{22}$; the price for oxytocin that the United Nations Population Fund currently has posted on its website is US\$0.28 per amp. ${ }^{23}$ And oxytocin is widely available and produced by many generic pharmaceutical manufacturers, although there are relatively few selling to low-and middle-income country markets that meet current global good manufacturing practices quality standards for oxytocin. For carbetocin to be a viable alternative to oxytocin, it would need to be similarly inexpensive and ubiquitous. It is reassuring to read that Ferring Pharmaceuticals, the sole supplier of carbetocin, hopes to make it "available in public-sector facilities of high-burden countries at an affordable and sustainable price,"1 but we're not there yet.

\section{A QUIVER OF UTEROTONICS}

Carbetocin is one of a suite of medicines that act on the myometrium and that, together, constitute an important set of tools for achieving better birth outcomes. It may be that carbetocin will eventually partially replace the use of some of the others for certain indications, in certain circumstances. But there will continue to be a need for oxytocin, misoprostol, tranexamic acid, and ergot alkyloids. Optimal strategies for how best to use this complement of drugs will vary by setting and need to take into account characteristics of the drugs, available evidence on effectiveness and safety, and the situation on the ground.

Competing Interests: None declared.

\section{REFERENCES}

1. Widmer M, Piaggio G, Nguyen TMH, et al; WHO CHAMPION Trial Group. Heat-stable carbetocin versus oxytocin to prevent hemorrhage after vaginal birth. N Engl J Med. 2018;379(8): 743-752. CrossRef. Medline

2. Mundasad S. Revamped drug could save lives of many new mothers - WHO. BBC News. June 28, 2018. https://www.bbc. $\mathrm{com} /$ news/world-asia-44617525. Accessed September 10, 2018.

\section{oxytocin.}


3. Meshykhi LS, Nel MR, Lucas DN. The role of carbetocin in the prevention and management of postpartum haemorrhage. Int $J$ Obstet Anesth. 2016;28:61-69. CrossRef. Medline

4. Hogerzeil HV, Walker GJA, de Goeje MJ. Stability of Injectable Oxytocics in Tropical Climates: Results of Field Surveys and Simulation Studies on Ergometrine, Methylergometrine and Oxyłocin. Geneva: World Health Organization; 1993. http://apps. who.int/medicinedocs/en/d/Js2205e/. Accessed September 10, 2018.

5. Stanton C, Koski A, Cofie P, Mirzabagi E, Grady BL, Brooke S. Uterotonic drug quality: an assessment of the potency of injectable uterotonic drugs purchased by simulated clients in three districts in Ghana. BMJ Open. 2012;2(3):pii: e000431. CrossRef. Medline

6. Stanton C, Nand DN, Koski A, et al. Accessibility and potency of uterotonic drugs purchased by simulated clients in four districts in India. BMC Pregnancy Childbirth. 2014;14:386. CrossRef. Medline

7. Torloni MR, Gomes Freitas C, Kartoglu UH, Metin Gülmezoglu A, Widmer M. Quality of oxytocin available in low- and middle-income countries: a systematic review of the literature. BJOG. 2016; 123(13):2076-2086. CrossRef. Medline

8. Adnan N, Conlan-Trant R, McCormick C, Boland F, Murphy DJ. Intramuscular versus intravenous oxyłocin to prevent postpartum haemorrhage at vaginal delivery: randomised controlled trial. $B M$. 2018;362:k3546. CrossRef. Medline

9. Westhoff G, Cotter AM, Tolosa JE. Prophylactic oxytocin for the third stage of labor to prevent postpartum hemorrhage. Cochrane Database Syst Rev. 2013;(10):CD001808. CrossRef. Medline

10. de Groot AN, van Roosmalen J, van Dongen PW, Borm GF. A placebo-controlled trial of oral ergometrine to reduce postpartum hemorrhage. Acta Obstet Gynecol Scand. 1996;75(5):464-468. Medline

11. Poeschmann RP, Doesburg WH, Eskes TK. A randomized comparison of oxytocin, sulprostone and placebo in the management of the third stage of labour. Br J Obstet Gynaecol. 1991 ; 98(6):528-530. Medline

12. Pierre F, Mesnard L, Body G. For a systematic policy of i.v. oxytocin inducted placenta deliveries in a unit where a fairly active management of third stage of labour is yet applied: results of a controlled trial. Eur J Obstet Gynecol Reprod Biol. 1992;43(2):131-135. Medline
13. Abdel-Aleem $H$, Singata $M$, Abdel-Aleem $M, M$ shweshwe $N$, Williams X, Hofmeyr GJ. Uterine massage to reduce postpartum hemorrhage after vaginal delivery. Int J Gynecol Obstet. 2010;11 1 (1):32-36. CrossRef. Medline

14. Nordstrom L, Fogelstam K, Fridman G, Larsson A, Rydhstroem $H$. Routine oxytocin in the third stage of labour: a placebo controlled randomised trial. Br J Obstet Gynaecol. 1997;104(7):781-786. Medline

15. Simpson KR, Knox GE. Oxytocin as a high-alert medication: implications for perinatal patient safety. MCN Am J Matern Child Nurs. 2009;34(1):8-15. CrossRef. Medline

16. Brhlikova $P$, Jeffery $P$, Bhatia GP, Khurana $S$. Intrapartum oxytocin (mis)use in South Asia. J Health Studies. 2009;2:33-50. https:// assets.publishing.service.gov.uk/media/57a08b5940f0b6497 4000ae2/60336_Intrapartum.pdf. Accessed September 10, 2018.

17. Day LT, Hruschka D, Mussell F, Jeffers E, Saha SL, Alam S. Perinatal mortality associated with use of uterotonics outside of Comprehensive Emergency Obstetric and Neonatal Care: a crosssectional study. Reprod Health. 2016;13(1):129. CrossRef. Medline

18. Flandermeyer D, Stanton C, Armbruster D. Uterotonic use at home births in low-income countries: a literature review. Int $J$ Gynaecol Obstet. 2010;108(3):269-75. CrossRef. Medline

19. Mullany LC, Khatry SK, Katz J. Injections during labor and intrapartum-related hypoxic injury and mortality in rural southern Nepal. Int J Gynaecol Obstet. 2013;122(1):22-26. CrossRef. Medline

20. Neogi SB, Sharma J, Negandhi P, Chauhan M, Reddy S, Sethy G. Risk factors for stillbirths: how much can a responsive health system prevent? BMC Pregnancy Childbirth. 2018;18(1): 33. CrossRef. Medline

21. Dujardin B, Boutsen M, De Schampheleire I, et al. Oxyłocics in developing countries. Int J Gynaecol Obstet. 1995;50:243-251 Medline

22. Oxyłocin. In: International Medical Products Price Guide. Arlington, VA: Management Sciences for Health; 2016. http://mshpriceguide. org/en/single-drug-information/?DMFId=580\&searchYear=2015. Accessed September 10, 2018.

23. Oxytocin $10 \mathrm{I}$. U./ml injection in $1 \mathrm{ml}$ ampoule. In: UNFPA Product Catalog. UNFPA Procurement Services website. Updated on July 9, 2018. hitps://www.unfpaprocurement.org/products?id= OXYTOCIN_1OIU/ML. Accessed September 10, 2018.

Cite this article as: Hodgins S. New evidence on carbetocin: another arrow in our quiver. Glob Health Sci Pract. 2018;6(3):405-407. https://doi.org/ 10.9745/GHSP-D-18-00336

(c) Hodgins. This is an open-access article distributed under the terms of the Creative Commons Attribution 4.0 International License (CC BY 4.0), which permits unrestricted use, distribution, and reproduction in any medium, provided the original author and source are properly cited. To view a copy of the license, visit http://creativecommons.org/licenses/by/4.0/. When linking to this article, please use the following permanent link: https://doi.org/ 10.9745/GHSP-D-18-00336 